\title{
Research on Tax Planning Based on High-tech Enterprises
}

\author{
Lu Wenxian \\ Xi'an Peihua University, Shaanxi Xi'an, China, 710125
}

Keywords: high-tech enterprise; tax planning; research

\begin{abstract}
The rapid development of China's market economy has brought certain opportunities to the development of high-tech enterprises. The quality of enterprise tax planning work and the quality of management will directly affect the economic efficiency and competitiveness of enterprises. Enterprises need to increase their emphasis on tax planning. Therefore, in order to ensure the stable and rapid development of high-tech enterprises, enterprises should pay attention to tax planning work. This paper analyzes the significance of tax planning for high-tech enterprises, studies the tax planning strategies of high-tech enterprises, and explores the risks and corresponding countermeasures of tax planning.
\end{abstract}

\section{Introduction}

In recent years, China's high-tech industry has developed at a relatively fast pace and has gradually become an important enterprise affecting the stability of China's social and economic development. High-tech industries are of great significance to promoting China's social and economic stability and healthy development and promoting the transformation of China's social and economic structure. The Chinese government gives high-tech enterprises certain policy support. In order to achieve stable and healthy development goals, high-tech enterprises need to improve the quality of tax planning work based on these preferential policies.

\section{The significance of tax planning for high-tech enterprises}

\subsection{Macro-control objectives can be achieved}

The macro-control policies formulated by the government departments will affect the development speed and development direction of enterprises, and taxation is an important way for the government to regulate enterprises. First, scientific and efficient tax planning is of great significance in reducing corporate tax burden and enhancing corporate enthusiasm. Second, government departments have scientifically formulated tax policies to regulate corporate tax planning, which rationally guide the circulation of social resources and improve the utilization of social resources. It is of great significance to promote the stable development of the social economy. Third, corporate tax planning will directly affect its development speed. Therefore, high-tech enterprises need to carry out tax planning reasonably. This will promote the sustainable 
development of China's high-tech industry and stimulate people's entrepreneurship and innovation enthusiasm significantly.

\subsection{Play an important role in corporate financial management}

\subsubsection{Corporate financial management objectives can be achieved}

Through scientific and efficient tax planning, corporate tax costs can be reduced and corporate economic benefits can be improved. Therefore, Chinese enterprises use tax planning methods to control the tax burden of enterprises and enhance their comprehensive competitiveness. High-tech enterprises are technology-intensive enterprises, so their cost management is different from that of ordinary enterprises. Therefore, high-tech enterprises need to reasonably plan their business operations and investment plans according to their development direction and corporate characteristics to ensure the rationality of tax planning. This will reduce the tax burden of enterprises and improve the economic efficiency of enterprises.

\subsubsection{Ensure that companies make scientific financial decisions}

Reasonable and efficient tax planning can ensure the scientific decision-making of high-tech enterprises. Fund-raising decisions, investment decisions, and production and operation decisions are all important factors influencing corporate financial decisions. Through tax planning, high-tech enterprises can obtain the most financing and economic benefits at the lowest cost, which is of great significance to the development of enterprises.

\subsubsection{Corporate financial management can be improved}

The development of any enterprise is inseparable from the development planning and development strategy of the enterprise. High-tech enterprises need to constantly adjust their development strategies and development plans according to the market environment and the development of the enterprise, so as to promote the stable and sustainable development of the enterprise. The tax planning policy integrates the financial management and development strategies of the enterprise, which is of great significance for the scientific formulation of financial policies, and at the same time can improve the financial management level of the enterprise.

\section{High-tech enterprise tax planning strategy}

\subsection{VAT tax planning strategy}

Different from other enterprises, high-tech enterprises have higher added value of products, so high-tech enterprises need to bear a large amount of value-added tax. However, output tax and deductible input tax will affect the value-added tax burden of enterprises, so high-tech enterprises can reasonably plan for VAT. High-tech enterprises can be reasonably planned by tax base and tax rate, thereby reducing the value-added tax burden of enterprises.

From the perspective of theoretical knowledge, in order to reduce the VAT tax burden, enterprises should minimize the VAT tax base. However, in the actual work process, the product sales price and the deductible input tax amount are the major factors of tax-inducing tax base.

According to the relevant laws and regulations of China, the general taxpayers who meet the relevant regulations can be converted into small-scale taxpayers. High-tech enterprises can choose the taxpayer identity according to this regulation, which is of great significance for enterprises to reduce tax rates and reduce tax burden. 
The settlement method will also affect the tax time. If a high-tech enterprise purchases a special VAT invoice for the current period when purchasing materials, it can appropriately deduct the current VAT tax; if the high-tech enterprise does not receive the payment in time when selling the product, it must choose the method of credit sales or installment. Deferred VAT payment time.

\subsection{Income tax planning strategy}

Another tax that high-tech enterprises need to pay is corporate income tax. Through reasonable tax planning, corporate tax burden can be effectively reduced and the economic benefits of enterprises can be improved. High-tech enterprises can adopt the following tax planning strategies: First, high-tech enterprises need to scientifically stipulate the time and method of payment of corporate income tax (for example, paying corporate income tax on a quarterly basis and annual basis). The payment time and method of different corporate income tax are different; secondly, High-tech enterprises must rationally carry out tax planning according to the tax preferential policies formulated by the state (China's government departments have formulated "three exemptions and three reductions" and R\&D expenses and deductions, etc. for high-tech enterprises with environmental protection), high-tech Enterprises need to plan according to these preferential policies and choose the best tax time and method. Finally, enterprises need to scientifically select appropriate accounting policies. High-tech enterprises can scientifically adjust enterprises by depreciating fixed assets according to the characteristics of the enterprise and tax laws depreciation amount distribution time.

\section{Risks of tax planning}

\subsection{The risk of changes in tax policy}

Tax planning is an ex ante activity, and it does not predict changes in tax policies and the effects of relevant policies. Due to the rapid development of China's social economy, China's relevant tax policies have changed rapidly. At the same time, China has not formulated a perfect taxation legal mechanism. Some taxes have not been reflected in the law, and relevant systems and measures are not perfect. Therefore, in the process of rapid development of the market economy, tax policies will also change. Any planning and planning of the enterprise shall be carried out in accordance with the tax policy. If the previous planning plan does not apply to the changed tax policy, the enterprise may violate the legal planning principle, causing the enterprise to face the risk of illegality.

\subsection{Risks that are not fully formed by tax planning}

In the process of tax planning, enterprises not only need to analyze and plan a certain kind of tax or a certain business, but the enterprise needs to plan and plan all tax types and businesses reasonably, so as to effectively reduce the tax burden of enterprises and improve the economic benefits of enterprises. If the company does not plan for all tax payment and business, it may reduce the tax burden of the enterprise, but it may also increase the cost of the enterprise. This will not achieve the purpose of reducing the tax burden of the enterprise, and the tax planning cannot fully play its role. The main purpose of tax planning for enterprises is to reduce the tax burden of enterprises and improve the economic benefits of enterprises. Therefore, corporate tax planners need to scientifically establish a holistic view, so as to ensure the comprehensiveness of tax planning work. 


\subsection{The risk of financial staff's tax planning awareness and insufficient capacity}

The theoretical knowledge of tax planning is more complicated, and the operation is more difficult. Tax planning work will also face a variety of uncertain factors. Therefore, in order to improve the quality of corporate tax planning work, enterprises need to establish a team of financial personnel with high tax planning ability, high level of professional knowledge and high comprehensive quality. Different from other financial management tasks, tax planning will involve many aspects of business operations planning is difficult. Therefore, tax planners need to fully grasp all the business activities of the company, and also need to master the knowledge of finance, taxation and management. In addition, in order to ensure the quality of tax planning work and improve the financial management level of enterprises, tax planners need to master the latest tax policy. It is based on the above requirements that enterprise-related workers need to have a high level of professional knowledge and professional quality. In this way, the quality of tax planning work can be guaranteed, the goal of reducing the tax burden of enterprises can be realized, and the stable and sustainable development of enterprises can be promoted. However, some enterprises in China have the following problems:

(1) The professional quality and professional knowledge of financial workers are not high enough, and the company lacks highly educated and highly qualified financial workers;

(2) financial personnel do not fully understand China's tax policy and have not established Tax planning awareness, and some financial personnel believe that the corporate income tax rate is not enough, no need to carry out tax planning, which is also an important reason for the heavy tax burden of enterprises;

(3) enterprises pay less attention to tax planning work, financial workers are proactively carry out tax planning;

(4) The taxation department of the enterprise shall be notified by the taxation department. In case of problems, according to the advice given by the taxation firm, the tax planning is not carried out independently. All of the above points will have a certain impact on the company.

\subsection{Less risk of communicating with the tax department}

In China, tax authorities at all levels are responsible for tax work, so the tax department has the right to decide tax planning. However, China's taxation legal system is relatively large, and it will involve departmental regulations and local regulations. However, some high-tech enterprises in China do not have enough funds, the number of talents is not enough, and the scale of enterprises is not large enough. Therefore, their management level is not high enough, and the latest laws are the understanding of regulations and tax policies is not deep enough. In order to ensure the rationality of the tax planning scheme, high-tech enterprises need to strengthen communication with the taxation department and obtain the latest tax knowledge and taxation policies in a timely manner.

\section{Corresponding preventive measures}

\subsection{Reasonable understanding of tax policy}

The main purpose of enterprises in tax planning is to reduce corporate tax burden and improve corporate economic efficiency based on China's tax policies and laws. Therefore, enterprises need to continuously optimize and improve tax planning according to tax policies and laws. First of all, in the process of tax planning, enterprises must strictly follow the relevant laws and regulations of China, which is the principle that every enterprise must follow. Therefore, high-tech enterprises must adhere to the principle of legality in the process of tax planning; secondly, corporate tax 
planners need to understand China's tax policy in a timely manner and rationally adjust the tax planning plan; again, enterprises need to strengthen internal inspections, so as to ensure corporate taxation. The planning plan complies with relevant laws and policy requirements and avoids tax risks arising from unreasonable tax planning schemes. In addition, due to the certain gap between the actual operation of tax planning and the tax law, enterprises need to scientifically adjust the amount of tax required by enterprises according to the tax law; enterprises must actively cooperate with the inspection of tax authorities; finally, corporate tax planners must actively learn the relevant knowledge of tax law. Improve your professional ability, professional knowledge, and timely understand the changes in tax policy and enhance their tax planning capabilities.

\subsection{Pay attention to the comprehensiveness of tax planning}

In the planning process, tax planners need to focus on the enterprise and analyze various factors in detail, so as to ensure the rationality of the planning plan and effectively reduce the corporate tax burden. In addition, in the planning process, tax planners need to scientifically formulate plans according to the development of the enterprise and development goals, and strictly prohibit the blind pursuit of taxation minimum. In order to improve the economic efficiency of enterprises, tax planners need to analyze the factors such as enterprise cost and risk in detail during the planning process. For example, enterprises need to invest part of the funds to recruit professional financial personnel and train staff; if a company needs to hire a professional organization to make recommendations, it also needs to invest part of the funds. Therefore, in the planning process, many factors need to be considered, so as to ensure the tax planning plan. The rationality and improvement of the economic benefits of the enterprise.

Tax cost management and risk control are important components of corporate tax management. When controlling tax risks, enterprises must ensure that their control measures comply with the law; enterprises must strictly control the cost of enterprises when controlling tax risks, so that the purpose of reducing enterprise costs and improving economic efficiency of enterprises can be achieved. The tax planners must do a good job in financial accounting according to the development goals and operations of the enterprise, and carry out scientific planning according to the existing taxation policies, so that the positive role of tax planning can be fully utilized.

\subsection{Improve the overall quality of financial personnel}

In actual work, taxpayers' tax planning time is mostly before their economic business, and tax policies, laws and regulations may change during this period, resulting in differences between results and expectations. Therefore, in order to improve the effectiveness of tax planning, high-tech enterprises should pay attention to tax planning work, and employ financial personnel with professional planning and planning skills to strengthen professional training for original employees and enhance their professional quality and professional ability. Real-time understanding of tax policies and legal changes, so as to effectively improve the financial management level of enterprises and reduce operational risks.

The implementation of corporate tax planning is also inseparable from the support of the leadership and financial personnel. Therefore, the leadership and financial personnel of high-tech enterprises need to actively learn new knowledge, continuously improve their professional quality and professional ability, and contribute their own strength to the company's development. In addition, enterprises need to continuously explore and cultivate specialized tax planning talents to ensure the scientific and complete planning of the program, reduce corporate tax burden and enhance the economic benefits of enterprises. 


\subsection{Strengthen communication with the tax authorities}

Any activity of the enterprise must be carried out in accordance with the law. The same is true for tax planning. Enterprises need to thoroughly study relevant laws and ensure the legality of the tax planning scheme so that illegal risks can be avoided. In addition, the financial personnel's understanding of the tax policy may not be comprehensive enough, and the tax authorities' understanding of these laws and policies is more in-depth and comprehensive. Therefore, there is a bias between the enterprise and the tax authorities in understanding the tax policy. Therefore, in order to ensure the legitimacy and rationality of the tax planning scheme, the financial personnel must actively communicate with the taxation department, so that the financial personnel can deeply understand the tax policy. You can also master the latest tax policies and laws, which is of great significance for companies to adjust their tax planning. In addition, whether the corporate tax planning program is legal or not needs to be examined and approved by the tax authorities. Therefore, enterprises need to strengthen communication with the taxation department, so that they can understand relevant policies, which is very important to improve the rationality of corporate tax planning and improve the economic efficiency of enterprises.

\section{Conclusion}

All in all, high-tech enterprises need to strengthen tax planning and management, which is of great significance to improving the comprehensive competitiveness of high-tech enterprises and promoting their stable and sustainable development. Therefore, high-tech enterprises need to correctly establish tax planning concepts, reasonably control corporate tax burdens, and take effective measures to control tax risks. At the same time, high-tech enterprises need to continuously improve tax planning activities in accordance with relevant policies and social and economic developments, so as to achieve the goal of sustainable development of high-tech enterprises.

\section{References}

[1] Zhou Hui, Zhao Pengfei. Discussion on Tax Planning of Construction Enterprises_—Based on the Tax Preference of High-tech Enterprises [J]. International Business Accounting, 2016(8): 88-89.

[2] Cheng Lu. Research on Tax Planning in the Production and Operation of High-Tech Enterprises [D]. 2016.

[3] Ren Tingting, Zhang Fangfang. Research on the Status Quo and Tax Planning of High-tech Enterprises in China

[J]. Times Finance, 2017(33): 119-120.

[4] Hu Aijun. Analysis of Tax Planning of High-tech Enterprises under the Policy of "Changing Reform and Increase" [J]. Accounting Research, 2017(17): 158-159.

[5] Liu Guifang. Tax Planning Direction of High-tech Enterprises Based on Financial Management Perspective [J]. Modern Economic Information, 2017(01): 280.

[6] Liu Yerong. Tax Planning of High-tech Enterprises Based on Life Cycle Theory [J]. Economist, 2017(5): 121-121. 